\title{
Age Group-Based Mean Differences in Recovery Speed from COVID-19 Infection Mpumalanga Province
}

\author{
Professor Bhekizizwe Mdlovu \\ E-mail of corresponding author: bhekizm@gmail.com
}

\begin{abstract}
The aim of this analysis was to examine mean differences in the speed of recovery (days) from COVID-19 infection by case-patients among age groups in Mpumalanga province. A sample of 5723 case-patients distributed among ten distinct age groups, beginning from 0-9 years. Using the date at which the result confirming positivity for each case was received and the date at which discharge occurred, the DATEDIF() function in Microsoft Excel was used to calculate the speed of recovery, measured by number of days. Time from infection to recovery was therefore measured as the number of days from first positive to first negative SARSCoV-2 PCR test result. Data was processed in both Excel and Statistical Package for Social Sciences (SPSS) prior to conducting statistical data analysis. The mean differences in the speed of recovery among age groups were analysed using the mean comparison Analysis of Variance (ANOVA) method. Age groups 0-9 years and 40-49 years had the longest average recovery speed of $17.32 \pm 8.84$ days and $17.22 \pm 7.88$ days; respectively, while the age group 70-79 years had the fastest average recovery speed of $15.43 \pm 4.51$ days. ANOVA results show no statistical evidence that the mean recovery speed (days) from differed significantly among age groups $\left(\mathrm{F}_{(8,5714)}\right.$ statistic $(=0.932 ; \mathrm{p}>0.05)$ at $5 \%$ significance level.
\end{abstract}

Key words: Age group mean differences, recovery speed, Covid 19, Mpumalanga Province

DOI: $10.7176 / \mathrm{JHMN} / 80-19$

Publication date:September $30^{\text {th }} 2020$

\section{Introduction}

Human coronaviruses have become common throughout the globe. Numerous different coronaviruses are identified in animals, while merely a small number of them can cause disease in human beings (Department of Health, 2020). The coronavirus disease 2019 (COVID-19) was first reported in December 2019 by the World Health Organization (WHO) country office following a cluster of pneumonia cases in Wuhan City, Hubei province, China (National Institute of Communicable Diseases, 2020). SARS-CoV-2 was confirmed as the causative virus of COVID-19, which has rapidly become a global pandemic continuing to spread across countries in the world. Most of the case-patients initially identified were dealers and vendors at a seafood, poultry and live wildlife market in China (WHO, 2020). According to the Department of Health (2020), people who are most at higher risk are the elderly, healthcare workers and those with co-morbidities.

The spread of the disease is believed to happen primarily via respiratory droplets produced when an infected person coughs or sneezes, similar to how influenza and other respiratory pathogens spread. The majority of cases have occurred in people with close physical contact to cases and healthcare workers proving health care services to patients with COVID-19 (National Institute of Communicable Diseases, 2020). COVID-19 basically affects all ages, and impacts other health conditions. Until the vaccine is found, the pandemic will remain as a serious global health threat. Since COVID-19 is a new disease, there is limited information regarding risk factors for severe diseases. In some cases, people who get COVID-19 can become seriously ill and develop difficulties in breathing, while severe complications can lead to death. The older population (50+ years) as well as those with underlying medical conditions like those who are immune-compromised like serious heart problems and chronic lung disease is more likely to develop serious illnesses.

Since outbreak, the pandemic has shown a low proportion of cases among young children (National Institute of Communicable Diseases, 2020). Age disparities in the observed cases are believed to be explained by children having lower susceptibility to infection, lower propensity to show clinical symptoms. The Center for Disease Control (2020) states that COVID-19 is a new disease and there is limited information regarding risk factors for severe disease. Based on currently available information and clinical expertise, older adults and people with underlying medical conditions have been observed to be at higher risk for severe illnesses from COVID-19. In terms of recovery rates, scientists and researchers globally are constantly tracking infections and recoveries. The data at disposal is only on confirmed cases and does not include people who do get COVID-19 tests. In addition, available data does not contain information about the outcome of every infection. Treatment is mainly supportive 
in form provision of oxygen for patients with shortness of breath, and other symptoms likes fever, dry cough and sore throat.

\subsection{Research Objective}

- To determine mean differences in the speed of recovery (days) from COVID-19 infection by casepatients among age groups in Mpumalanga province.

\subsection{Research Question}

- Are there mean differences in the speed of recovery (days) from COVID-19 infection by case-patients among age groups in Mpumalanga province?

\subsection{Research Hypothesis}

- There are mean differences in the speed of recovery (days) from COVID-19 infection by case-patients among age groups in Mpumalanga province.

\subsection{Significance of the Study}

The results from this analysis are expected to contribute greatly towards developing mechanisms that can be deemed relevant to help curtail the spread of the disease among age groups in the province. In terms of monitoring the disease spread, findings are expected to provide insights on age groups where mapping and tracking would need to be continuously conducted using relevant intelligence mechanisms and approaches

\section{Methodology}

\subsection{Design}

A descriptive research design was used in this research study. The categorical factor was age group, while and dependent variable was the recovery speed measured using the number of days taken to full recovery.

\subsection{Population and Sample}

The population for the study was patients who got infected and first tested positive from the first SARS CoV-2 PCR test and later tested negative to SARS-CoV-2 PCR test after a certain period. The sample consists of 5723 clinically confirmed recovered cases as at 21 July 2020.

\subsection{Data}

The secondary dataset used in the analysis was obtained from Mpumalanga Department of Health (MDoH). Data cleaning and processing was initially conducted in Excel and Statistical Package for Social Sciences (SPSS) prior to conducting statistical data analysis. The variable "recovery speed (days)" was calculated by inserting the date at which the result confirming positivity was received and the date discharge occurred into the DATEDIF() function in Excel. Thus, time from infection to recovery is measured as the number of days from first positive to first negative SARSCoV-2 PCR test result.

\subsection{Treatment}

The sample was categorised into nine distinct 10-year interval age groups, beginning from 0-9 years.

\subsection{Statistical Analysis Technique}

The univariate one-way Analysis of Variance (ANOVA) statistical technique was applied to examine mean differences in the recovery speed (days) from COVID-19 infection; based on the following function.

$$
F\left(v_{i j}, w_{i j}\right) \leq h
$$

where $\mathrm{F}$ represents the function which transforms $\mathrm{w}$ into $\mathrm{v}$; with $\mathrm{v}$ denoting recovery speed (days) of the $\mathrm{i}^{\text {th }}$ case in district $\mathrm{j}$; $\mathrm{w}$ represents the $\mathrm{i}^{\text {th }}$ positivity and discharge record applied to age group $\mathrm{j}$; and $\mathrm{h}$ denotes a positive scalar, which overall further reduces to:

$$
R S_{i j}=\lambda_{j}+\lambda_{j} G_{i j}+\varepsilon_{i k}
$$


where RS is the recovery speed (days) of the $i^{\text {th }}$ case in district $j$; $G$ represents the age group on the $i^{\text {th }}$ case in age group $\mathrm{j}$; and $\lambda_{\mathrm{j}}$ denotes the average speed of recovery attributed to a specific age group. Descriptive statistics were computed to analyse the means, standard deviation and standard error estimates; while the ANOVA Tukey HSD post hoc test was used to examine whether any significant differences existed between the patients' mean recovery speeds for each age group at 5 percent level of significance.

\section{Results and Analysis}

\subsection{Frequencies}

Table 1: Frequencies

\begin{tabular}{|l|c|c|c|}
\hline Age group & Frequency & Percent & Cumulative Percent \\
\hline 0-9 years & 192 & 3.4 & 3.4 \\
10-19 years & 321 & 5.6 & 9 \\
\hline 20-29 years & 925 & 16.2 & 25.1 \\
\hline 30-39 years & 1831 & 32.0 & 57.1 \\
\hline 40-49 years & 1208 & 21.1 & 78.2 \\
\hline $50-59$ years & 829 & 14.5 & 92.7 \\
\hline $60-69$ years & 306 & 5.3 & 98.1 \\
\hline $70-79$ years & 69 & 1.2 & 99.3 \\
\hline$>=80$ years & 42 & 0.7 & 100 \\
\hline Total & $\mathbf{5 7 2 3}$ & $\mathbf{1 0 0}$ & \\
\hline
\end{tabular}

Table 1 presents frequencies of case-patients per each age group. Results show that the age group 30-39 years accounted for the largest proportion of $32 \%(n=1831)$, followed by the age group 40-49 years which accounted for $21 \%(\mathrm{n}=1208)$ of the cases. The age group with the third highest proportion is the $20-29$ years with $16 \%(\mathrm{n}$ $=925$ ) cases, while the age group with the fourth highest proportion is 50-59 years which accounted for approximately $15 \%(n=829)$ of the cases.

\subsection{Descriptive Statistics}

Table 2: Descriptive statistics

\begin{tabular}{|l|c|c|c|c|}
\hline \multirow{2}{*}{ Age group } & \multirow{2}{*}{$\mathbf{N}$} & \multirow{2}{*}{ Mean (Std Dev) } & \multicolumn{2}{|c|}{$\mathbf{9 5 \%}$ Confidence Interval for Mean } \\
\cline { 4 - 5 } & & $17.32 \pm 8.84$ & 16.06 & Upper Bound \\
\hline 0-9 years & 192 & $16.55 \pm 6.71$ & 15.81 & 18.58 \\
10-19 years & 321 & $16.69 \pm 6.97$ & 16.24 & 17.29 \\
20-29 years & 925 & $16.79 \pm 7.15$ & 16.46 & 17.12 \\
30-39 years & 1831 & $17.22 \pm 7.88$ & 16.77 & 17.67 \\
40-49 years & 1208 & $16.92 \pm 7.34$ & 16.42 & 17.42 \\
$50-59$ years & 829 & $16.86 \pm 7.65$ & 16.00 & 17.72 \\
60-69 years & 306 & $15.43 \pm 4.51$ & 14.35 & 16.52 \\
70-79 years & 69 & $16.93 \pm 6.89$ & 14.78 & 19.07 \\
\hline$=80$ years & 42 & $\mathbf{1 6 . 8 8} \pm \mathbf{7 . 5 3}$ & $\mathbf{1 6 . 6 9}$ & $\mathbf{1 7 . 0 7}$ \\
\hline Total & $\mathbf{5 7 2 3}$ & &
\end{tabular}

Table 2 presents descriptive statistics for the speed (days) at which patient cases recovered from the disease across age groups in Mpumalanga province. From the entire sample of five thousand seven hundred and twentythree ( $\mathrm{n}=5$ 723) COVID-19 infected cases, the age groups 0-9 years and 40-49 years had the longest average recovery speed of $17.32 \pm 8.84$ days and $17.22 \pm 7.88$ days; respectively. The age group $70-79$ years had the fastest average recovery speed of $15.43 \pm 4.51$ days. 


\subsection{ANOVA Statistics}

Table 3: Test of homogeneity of variances

\begin{tabular}{|l|c|c|c|}
\hline \multicolumn{4}{|c|}{ Recovery speed (days) } \\
\hline Levene Statistic & df1 & df2 & Sig. \\
\hline 2.551 & 8 & 5714 & .009 \\
\hline
\end{tabular}

The Levene statistics (F-statistic $=2.551 ; \mathrm{p}<0.05)$, which tests for the assumption of homogeneity of variance show evidence of existence of significant differences in the variances of age groups. Therefore, the assumption of homogeneity of variance was not satisfied.

Table 4: ANOVA

\begin{tabular}{|l|c|c|c|c|c|}
\hline \multicolumn{7}{|c|}{ Recovery speed (days) } \\
\hline & Sum of Squares & df & Mean Square & F & Sig. \\
\hline Between Groups & 403.335 & 8 & 50.417 & .932 & .488 \\
Within Groups & 308937.801 & 5714 & 54.067 & & \\
\hline Total & 309341.136 & 5722 & & & \\
\hline
\end{tabular}

Table 4 ANOVA results show no statistical evidence that the mean recovery speed (days) from COVID-19 infection differed significantly among age groups $\left(F_{(8,5714)}\right.$ statistic $(=0.932 ; p>0.05)$ at $5 \%$ level of significance. To validate that there were no significant differences in average recovery speeds in case patients among all age groups, the Turkey HSD post hoc test were conducted, with results presented below.

Table 5: Multiple comparisons

Dependent Variable: Recovery speed (days)

Tukey HSD

\begin{tabular}{|c|c|c|c|c|c|c|}
\hline \multirow[t]{2}{*}{ (I) Age group } & \multirow[t]{2}{*}{ (J) Age group } & \multirow{2}{*}{$\begin{array}{c}\text { Mean } \\
\text { Difference (I-J) }\end{array}$} & \multirow[t]{2}{*}{ Std. Error } & \multirow[t]{2}{*}{ Sig. } & \multicolumn{2}{|c|}{ 95\% Confidence Interval } \\
\hline & & & & & Lower Bound & Upper Bound \\
\hline \multirow{8}{*}{$0-9$ years } & 10-19 years & .769 & .671 & .967 & -1.31 & 2.85 \\
\hline & 20-29 years & .624 & .583 & .978 & -1.19 & 2.43 \\
\hline & 30-39 years & .525 & .558 & .991 & -1.21 & 2.26 \\
\hline & 40-49 years & .098 & .571 & 1.000 & -1.68 & 1.87 \\
\hline & $50-59$ years & .399 & .589 & .999 & -1.43 & 2.23 \\
\hline & $60-69$ years & .458 & .677 & .999 & -1.64 & 2.56 \\
\hline & $70-79$ years & 1.883 & 1.032 & .666 & -1.32 & 5.09 \\
\hline & $>=80$ years & .389 & 1.253 & 1.000 & -3.50 & 4.28 \\
\hline \multirow{8}{*}{ 10-19 years } & $0-9$ years & -.769 & .671 & .967 & -2.85 & 1.31 \\
\hline & 20-29 years & -.146 & .476 & 1.000 & -1.62 & 1.33 \\
\hline & $30-39$ years & -.245 & .445 & 1.000 & -1.63 & 1.14 \\
\hline & 40-49 years & -.672 & .462 & .876 & -2.10 & .76 \\
\hline & $50-59$ years & -.371 & .483 & .998 & -1.87 & 1.13 \\
\hline & 60-69 years & -.311 & .587 & 1.000 & -2.13 & 1.51 \\
\hline & $70-79$ years & 1.114 & .976 & .968 & -1.91 & 4.14 \\
\hline & $>=80$ years & -.380 & 1.207 & 1.000 & -4.12 & 3.36 \\
\hline \multirow{8}{*}{$20-29$ years } & $0-9$ years & -.624 & .583 & .978 & -2.43 & 1.19 \\
\hline & 10-19 years & .146 & .476 & 1.000 & -1.33 & 1.62 \\
\hline & 30-39 years & -.099 & .297 & 1.000 & -1.02 & .82 \\
\hline & 40-49 years & -.526 & .321 & .784 & -1.52 & .47 \\
\hline & $50-59$ years & -.225 & .352 & .999 & -1.32 & .87 \\
\hline & 60-69 years & -.165 & .485 & 1.000 & -1.67 & 1.34 \\
\hline & $70-79$ years & 1.259 & .918 & .908 & -1.59 & 4.11 \\
\hline & $>=80$ years & -.235 & 1.160 & 1.000 & -3.83 & 3.37 \\
\hline \multirow{6}{*}{$30-39$ years } & $0-9$ years & -.525 & .558 & .991 & -2.26 & 1.21 \\
\hline & 10-19 years & .245 & .445 & 1.000 & -1.14 & 1.63 \\
\hline & 20-29 years & .099 & .297 & 1.000 & -.82 & 1.02 \\
\hline & 40-49 years & -.427 & .273 & .823 & -1.27 & .42 \\
\hline & $50-59$ years & -.126 & .308 & 1.000 & -1.08 & .83 \\
\hline & 60-69 years & -.066 & .454 & 1.000 & -1.48 & 1.34 \\
\hline
\end{tabular}




\begin{tabular}{|c|c|c|c|c|c|c|}
\hline & $\begin{array}{l}70-79 \text { years } \\
>=80 \text { years }\end{array}$ & $\begin{array}{l}1.358 \\
-.136\end{array}$ & $\begin{array}{c}.902 \\
1.148\end{array}$ & $\begin{array}{l}.853 \\
1.000\end{array}$ & $\begin{array}{l}-1.44 \\
-3.70\end{array}$ & $\begin{array}{l}4.16 \\
3.43\end{array}$ \\
\hline \multirow{8}{*}{$40-49$ years } & $0-9$ years & -.098 & .571 & 1.000 & -1.87 & 1.68 \\
\hline & $10-19$ years & .672 & .462 & .876 & -.76 & 2.10 \\
\hline & 20-29 years & .526 & .321 & .784 & -.47 & 1.52 \\
\hline & 30-39 years & .427 & .273 & .823 & -.42 & 1.27 \\
\hline & 50-59 years & .301 & .332 & .993 & -.73 & 1.33 \\
\hline & $60-69$ years & .361 & .471 & .998 & -1.10 & 1.82 \\
\hline & $70-79$ years & 1.785 & .910 & .570 & -1.04 & 4.61 \\
\hline & $>=80$ years & .292 & 1.154 & 1.000 & -3.29 & 3.87 \\
\hline \multirow{8}{*}{$50-59$ years } & $0-9$ years & -.399 & .589 & .999 & -2.23 & 1.43 \\
\hline & $10-19$ years & .371 & .483 & .998 & -1.13 & 1.87 \\
\hline & 20-29 years & .225 & .352 & .999 & -.87 & 1.32 \\
\hline & $30-39$ years & .126 & .308 & 1.000 & -.83 & 1.08 \\
\hline & 40-49 years & -.301 & .332 & .993 & -1.33 & .73 \\
\hline & $60-69$ years & .060 & .492 & 1.000 & -1.47 & 1.59 \\
\hline & 70-79 years & 1.484 & .921 & .799 & -1.37 & 4.34 \\
\hline & $>=80$ years & -.009 & 1.163 & 1.000 & -3.62 & 3.60 \\
\hline \multirow{8}{*}{$60-69$ years } & $0-9$ years & -.458 & .677 & 999 & -2.56 & 1.64 \\
\hline & 10-19 years & .311 & .587 & 1.000 & -1.51 & 2.13 \\
\hline & 20-29 years & .165 & .485 & 1.000 & -1.34 & 1.67 \\
\hline & 30-39 years & .066 & .454 & 1.000 & -1.34 & 1.48 \\
\hline & 40-49 years & -.361 & .471 & .998 & -1.82 & 1.10 \\
\hline & $50-59$ years & -.060 & .492 & 1.000 & -1.59 & 1.47 \\
\hline & $70-79$ years & 1.425 & .980 & .877 & -1.62 & 4.47 \\
\hline & $>=80$ years & -.069 & 1.210 & 1.000 & -3.82 & 3.69 \\
\hline \multirow{8}{*}{$70-79$ years } & 0-9 years & -1.883 & 1.032 & .666 & -5.09 & 1.32 \\
\hline & 10-19 years & -1.114 & .976 & .968 & -4.14 & 1.91 \\
\hline & 20-29 years & -1.259 & .918 & .908 & -4.11 & 1.59 \\
\hline & 30-39 years & -1.358 & .902 & .853 & -4.16 & 1.44 \\
\hline & 40-49 years & -1.785 & .910 & .570 & -4.61 & 1.04 \\
\hline & $50-59$ years & -1.484 & .921 & .799 & -4.34 & 1.37 \\
\hline & 60-69 years & -1.425 & .980 & .877 & -4.47 & 1.62 \\
\hline & $>=80$ years & -1.494 & 1.439 & .982 & -5.96 & 2.97 \\
\hline \multirow{8}{*}{$>=80$ years } & $0-9$ years & -.389 & 1.253 & 1.000 & -4.28 & 3.50 \\
\hline & 10-19 years & .380 & 1.207 & 1.000 & -3.36 & 4.12 \\
\hline & 20-29 years & .235 & 1.160 & 1.000 & -3.37 & 3.83 \\
\hline & 30-39 years & .136 & 1.148 & 1.000 & -3.43 & 3.70 \\
\hline & 40-49 years & -.292 & 1.154 & 1.000 & -3.87 & 3.29 \\
\hline & $50-59$ years & .009 & 1.163 & 1.000 & -3.60 & 3.62 \\
\hline & $60-69$ years & .069 & 1.210 & 1.000 & -3.69 & 3.82 \\
\hline & 70-79 years & 1.494 & 1.439 & .982 & -2.97 & 5.96 \\
\hline
\end{tabular}

The Tukey post hoc tests results show that the mean recovery speed of case-patients in each age group did not differ significantly from average recovery speeds of case-patients in other age groups. Therefore, no significant differences existed in mean recovery speeds among case-patients across all age groups. 
Table 6: Homogeneous subsets

\begin{tabular}{|c|c|c|}
\hline \multicolumn{3}{|c|}{ Recovery speed (days) } \\
\hline Tukey HSD ${ }^{\mathrm{a}, \mathrm{b}}$ & & \\
\hline \multirow{2}{*}{ Age group } & \multirow{2}{*}{$\mathrm{N}$} & Subset for alpha $=0.05$ \\
\hline & & 1 \\
\hline $70-79$ years & 69 & 15.43 \\
\hline $10-19$ years & 321 & 16.55 \\
\hline $20-29$ years & 925 & 16.69 \\
\hline 30-39 years & 1831 & 16.79 \\
\hline $60-69$ years & 306 & 16.86 \\
\hline $50-59$ years & 829 & 16.92 \\
\hline$>=80$ years & 42 & 16.93 \\
\hline 40-49 years & 1208 & 17.22 \\
\hline $0-9$ years & 192 & 17.32 \\
\hline Sig. & & .314 \\
\hline \multicolumn{3}{|c|}{ Means for groups in homogeneous subsets are displayed. } \\
\hline \multicolumn{3}{|c|}{$\begin{array}{l}\text { a. Uses Harmonic Mean Sample Size }=168.051 . \\
\text { b. The group sizes are unequal. The harmonic mean of the group sizes is used. Type I error levels are not } \\
\text { guaranteed. }\end{array}$} \\
\hline
\end{tabular}

Homogenous subsets are an alternate approach regarded to be more suitable for computing and displaying the post hoc tests largely when group sizes are quite different. The null hypothesis of the subsets establishes that groups computed in the same subset are not significantly different. Results presented in Table 6 indicate no evidence of significant differences in average speed of recovery by case patients among all age groups.

\section{Conclusion Remarks}

This research study found no evidence of statistically significant differences in the average recovery speed (days) from COVID-19 infection case patients across all age groups. The findings imply that provision of clinical and health-related interventions aimed at curbing the spread of the COVID-19 disease should not be differentiated based on age group since the average recovery speeds among case-patients across all age groups are not statistically significantly different.

\section{References}

Department of Health. (2020). Corona Virus(COVID-19) Pandemic. Republic of South Africa.

World Health Organisation. (2019). Coronavirus disease (COVID-19) pandemic. https://www.who.int/emergencies/diseases/novel-coronavirus-2019

Kai-Wang To, K, Tak-Yin Tsang, O, Chik-Yan Yip, C, Chan, KH, Wu, TC, Man-Chun Chan, J...Yuen, KY. (2020). Consistent detection of 2019 novel coronavirus in saliva. Clinical Infectious Diseases. 12 February 2020. ciaa149.

https://academic.oup.com/cid/advance-article/doi/10.1093/cid/ciaa149/5734265external icon

WHO. Clinical management of severe acute respiratory infection when COVID-19 is suspected. 13 March 2020. https://www.who.int/publications-detail/clinical-management-of-severe-acute-respiratory-infection-whennovel-coronavirus-(ncov)-infection-is-suspectedexternal icon

The Novel Coronavirus Pneumonia Emergency Response Epidemiology Team. (2020). The epidemiological characteristics of an outbreak of 2019 novel coronavirus diseases (COVID-19) - China 2020. CCDCweekly.10.46234/ccdcw2020.03210.46234/ccdcw2020.032external icon10.46234/ccdcw2020.032external icon 10.46234/ccdcw2020.032external icon

WHO. Infection prevention and control during health care when novel coronavirus (nCoV) infection is suspected. 19 March 2020. https://www.who.int/publications-detail/infection-prevention-and-control-duringhealth-care-when-novel-coronavirus-(ncov)-infection-is-suspected-20200125external icon 
WHO. Rational use of personal protective equipment for coronavirus disease (COVID-19) and considerations during severe shortages. 6 April 2020. https://apps.who.int/iris/bitstream/handle/10665/331695/WHO-2019nCov-IPC PPE use-2020.3-eng.pdfpdf iconexternal icon 